\title{
U.S. REIT INDUSTRY PROFITABILITY: A BENNET DECOMPOSITION OF INDUSTRY DYNAMICS
}

\author{
Zhilan FENG ${ }^{1}$, Stephen M. MILLER (D) ${ }^{2}$, Dogan TIRTIROGLU ${ }^{3, *}$ \\ ${ }^{1}$ The David D. Reh School of Business, Clarkson University, 13699-5805 New York, USA \\ ${ }^{2}$ Department of Economics, University of Nevada, Las Vegas, USA \\ ${ }^{3}$ Real Estate Management Department, Ted Rogers School of Management, Ryerson University, ON M5G 2C3, \\ Toronto, Canada
}

Received 14 February 2020; accepted 08 February 2021

\begin{abstract}
This paper considers the aggregate profitability performance of the REIT industry. The aggregate performance depends on the underlying microeconomic dynamics within an industry - the growth of individual REITs (the within effect), the reallocation between existing REITs (the between effect), the entry of new REITs (the entry effect), and the exit of the existing REITs (the exit effect). We apply an extended Bennet (1920) dynamic decomposition on the REIT industry's return on equity (ROE) and study the annual data on U.S. Equity REITs for the 1989 to 2015 period and various REIT industry specific sub-sample periods. Bailey et al's (1992) and Haltiwanger's (1997) dynamic industry performance decompositions are special cases of the Bennet decomposition. The "within" and "between" effects dominate the annual changes in this industry's ROE. To the extent that our Equity REIT sample proxies for the FTSE NAREIT All Equity Index, our conclusions also relate to this index's profitability performance between 1989 and 2015.
\end{abstract}

Keywords: aggregate fluctuations, dynamic decomposition, ROE changes.

\section{Intruduction}

The U.S. Real Estate Investment Trust (REIT) industry provides fertile ground for cultivating research on industry dynamics. The industry has experienced immense growth, expansion, and some consolidation, especially since accomplishing its first-ever listing on the S\&P500 Index in October 2001 and weathering the Global Financial Crisis (GFC) of 2007-2008. An examination of the National Association of Real Estate Investment Trusts (NAREIT) (2020a) webpage yields the following observations: (1) At the end of 1971, only 34 REITs existed, of which 12 were Equity REITs, 12 were Mortgage REITs, and the remaining 10 were Hybrid REITs, with market capitalizations in the neighborhood of \$332, \$571, and \$592 million, respectively; (2) At the end of 2019, 219 REITs existed, of which 179 were Equity REITs and 40 were Mortgage REITs, with market capitalizations in the neighborhood of $\$ 1,246$ trillion and $\$ 83$ billion, respectively (https://www.reit.com/ data-research/reit-market-data/us-reit-industry-equitymarket-cap). The historical development of U.S. institutions, with a strong aversion to concentration of power and with significant regulation in the REIT sector ${ }^{1}$ since the early 1960s, has generated a competitive, highly successful, transparent, and innovative industry that has significantly surpassed its counterparts elsewhere. In fact, the U.S. model and experience have proved the main motivation for the formal development of the REIT industry in several countries, including Australia, Japan, France, and the United Kingdom since the early 2000s.

In this paper, we study empirically the evolution of the annual changes in the aggregated profitability of the REIT industry by employing the Bennet (1920) decomposition method. High capital intensity characterizes the REIT industry, which has been operating under regulation to transform illiquid income-producing real estate assets into liquid and tradeable assets. Further, REITs must maintain or enjoy prompt access to substantial cash reserves to meet, at a minimum, the legally mandated periodic dividend payout ratio. Institutional investors, including

\footnotetext{
1 Legislation has offered tax-exemption if REITs fulfill legally specified dividend payment and other requirements.
}

${ }^{*}$ Corresponding author. E-mail: dtirtiroglu@ryerson.ca 
pension funds, have increased their ownership of REITs and used periodic and relatively predictable cash inflows from REITs to meet their cash outflow needs. So, the public must maintain its confidence in the soundness of the REIT industry.

The pattern of REIT entries, mergers, and exits has generated dynamic fluctuations in both the number and size of REIT organizations, affecting differentially the REIT industry's profitability and concentration across time. So, after adopting Bennet's (1920) approach, we decompose dynamically the REIT industry's annual "changes in ROE" into factors attributable to improved profitability of individual REITs ("within" effect), shifts of resources from less to more profitable REITs ("between" effect), entries of more profitable REITs ("entry" effect), and exits of less profitable REITs ("exit and conversion" effect) between 1989 and $2015 .^{2}$ We focus mainly on the evolution of the "within" and "between" effects since those that enter the industry join shortly the ranks of survivors and those that exit present severe post-exit data challenges.

We measure the annual profitability of the REIT industry by the aggregated industry return on equity (ROE). The National Association of Real Estate Investment Trusts (NAREIT) has championed the use of the Funds From Operations (FFO) metric since the 1990s so as to provide a more informative measurement of REITs' operating performance. According to NAREIT (2020b), FFO equals "a REIT's net income, excluding gains or losses from sales of property, and adding back real estate depreciation" (https://www.reit.com/what-reit/glossary-reit-terms). FFO-based results may also prove consistent with REITs' expertise in managing their tax affairs. ${ }^{3}$ Further, the extant literature reports evidence that the FFO metric provides more information than the Net Income (NI) metric (Bhattacharya et al., 2003; Lougee \& Marquardt, 2004; BenShahar et al., 2011). So, we use the FFO metric in defining the aggregated industry ROE.

Some other industry performance decomposition measures (Bailey et al., 1992; Haltiwanger, 1997) are in fact special cases of the Bennet decomposition. The dynamic decomposition of industry performance requires microlevel information on firms - REITs in our paper - within an industry. The availability of micro-level (i.e., establish-

\footnotetext{
2 Note that the reverse effect could occur. That is, we could see worsened profitability of individual REITs ("within" effect), shifts of resources from more to less profitable REITs ("between" effect), entries of less profitable REITs ("entry" effect), and exits of more profitable REITs ("exit and conversion" effect).

3 Prescott and Visscher (1980) recognize organization(al) capital (OC) and define it as the accumulation and use of private information to enhance the production efficiency within a firm. OC refers to an organization's intellectual capital, an intangible asset that produces significant value. REITs, as creatures of tax exemptions, should possess unique $\mathrm{OC}$ in managing their cash flows through their expertise in tax matters, including depreciation allowances. See Devos et al. (2018) for evidence from a sample of REITs.
}

ment-level) data for manufacturing industries spawned a series of such applied microeconomic research. ${ }^{4}$ That research effort reveals more heterogeneity among firms and plants within the same industry than between industries. In sum, aggregate industry data contain important firmand plant-level dynamics that collectively determine overall industry dynamics.

The U.S. REIT industry has evolved over time and experienced different episodes of development and growth, now known as the Vintage Era (1960-1990 or 1991), the New REIT Era (1991 or 1992-2001), and, following Cakici et al. (2014), the REIT Maturity Era (2002-present time). The REIT Maturity Era has its beginning in the first-ever listing of a REIT in the S\&P500 Index in October 2001 and covers the Global Financial Crisis (GFC). The beginning of this era represents an endogenous accomplishment of the industry while the previous two depend fundamentally on regulators' tax law interventions. Panel A of Figure 1 illustrates considerable fluctuations in the annual total number of REITs and the corresponding market capitalizations between 1971 and 2017. The Vintage Era includes fewer Equity REITs with small equity market capitalization. The New REIT Era captures a quick increase in the number of Equity REITs, which then tends to stabilize around 150 institutions, and exhibits modest growth in capitalization. The REIT Maturity Era witnesses reasonably constant numbers of Equity REITs and rapid growth in their capitalization. The number of Equity REITs as well as their capitalization fell dramatically before the GFC of 2008-2009. Panel $B$ of Figure 1 shows the annual total and price returns on REITs and reveals that total returns reflect mainly the price returns. Also, falling total or price returns frequently signals a recession. The fall in these returns before the GFC was just over 70 percentage points. Data obstacles on FFO restrict our sample period to 1989-2015, which covers the latter two eras and allows for a comparative examination of the differences on our research questions across the REITindustry specific time periods.

Our work sheds light on a number of questions on the profitability of (1) the overall REIT industry and (2) following after Chen et al. (2012), the More- and Lesstransparent segments of the industry. ${ }^{5}$ To the extent that

\footnotetext{
4 McGuckin (1995) describes the Longitudinal Research Database (LRD) at the U.S. Bureau of the Census upon which this research relies. For banking data at the individual bank level, see the Federal Reserve Bank of Chicago (2020), https:// www.chicagofed.org/banking/financial-institution-reports/ commFercial-bank-data.

5 Equity REIT sub-samples of Apartments, Industrials, Offices, Regional Malls and Shopping Centers (all remaining Equity REIT sub-samples) are components of the More-transparent (Less-transparent) sub-sample, respectively. We also note that studying the incremental information content of the FFO metric is beyond the scope of our paper. Yet, unreported NI-based results differ considerably from their FFO-based counterparts, offering preliminary evidence of the difference in informational content of the FFO metric even at the industry level.
} 


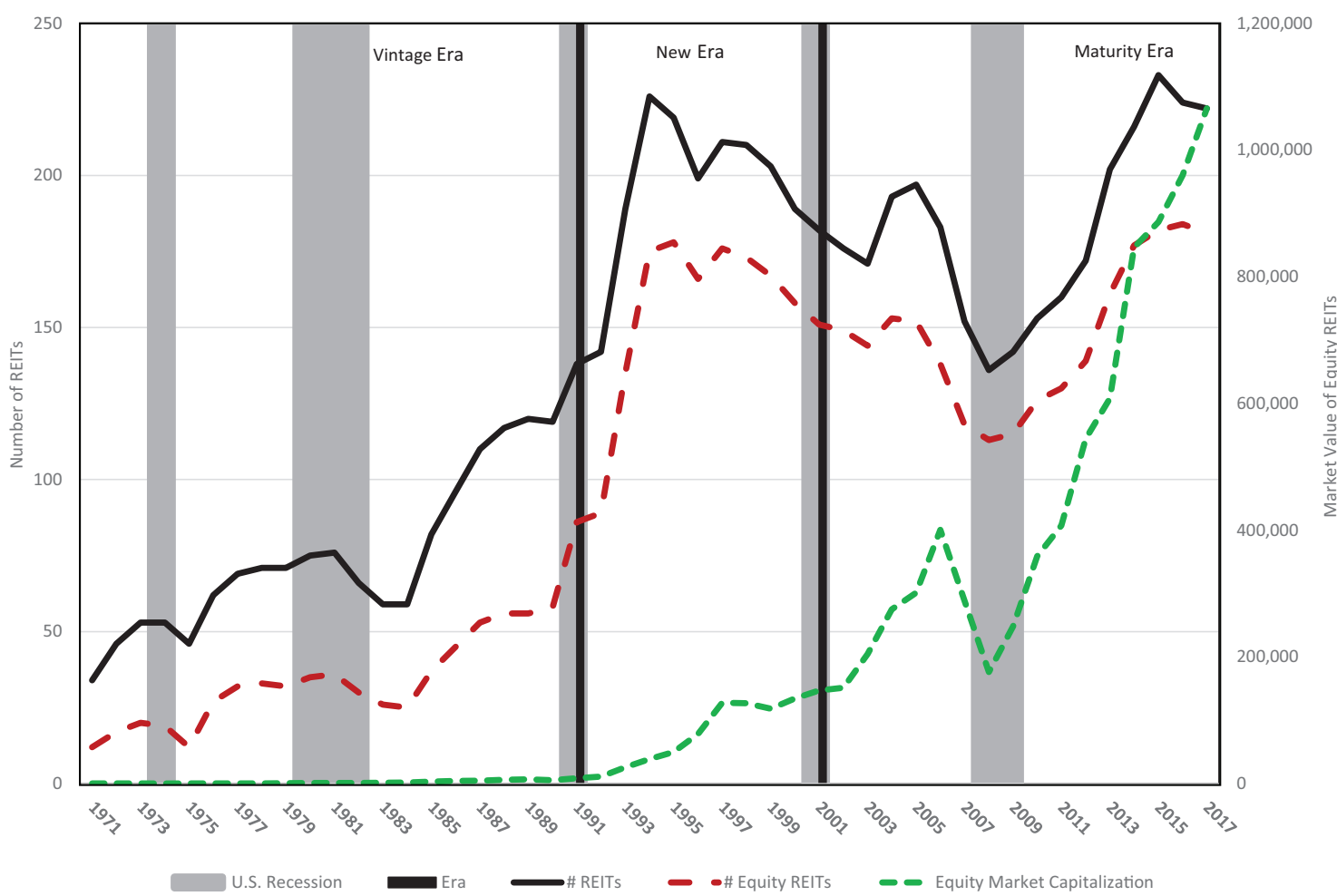

Panel A: Annual number and annual total market value of REITs as covered in the FTSE-NAREIT All REIT Index

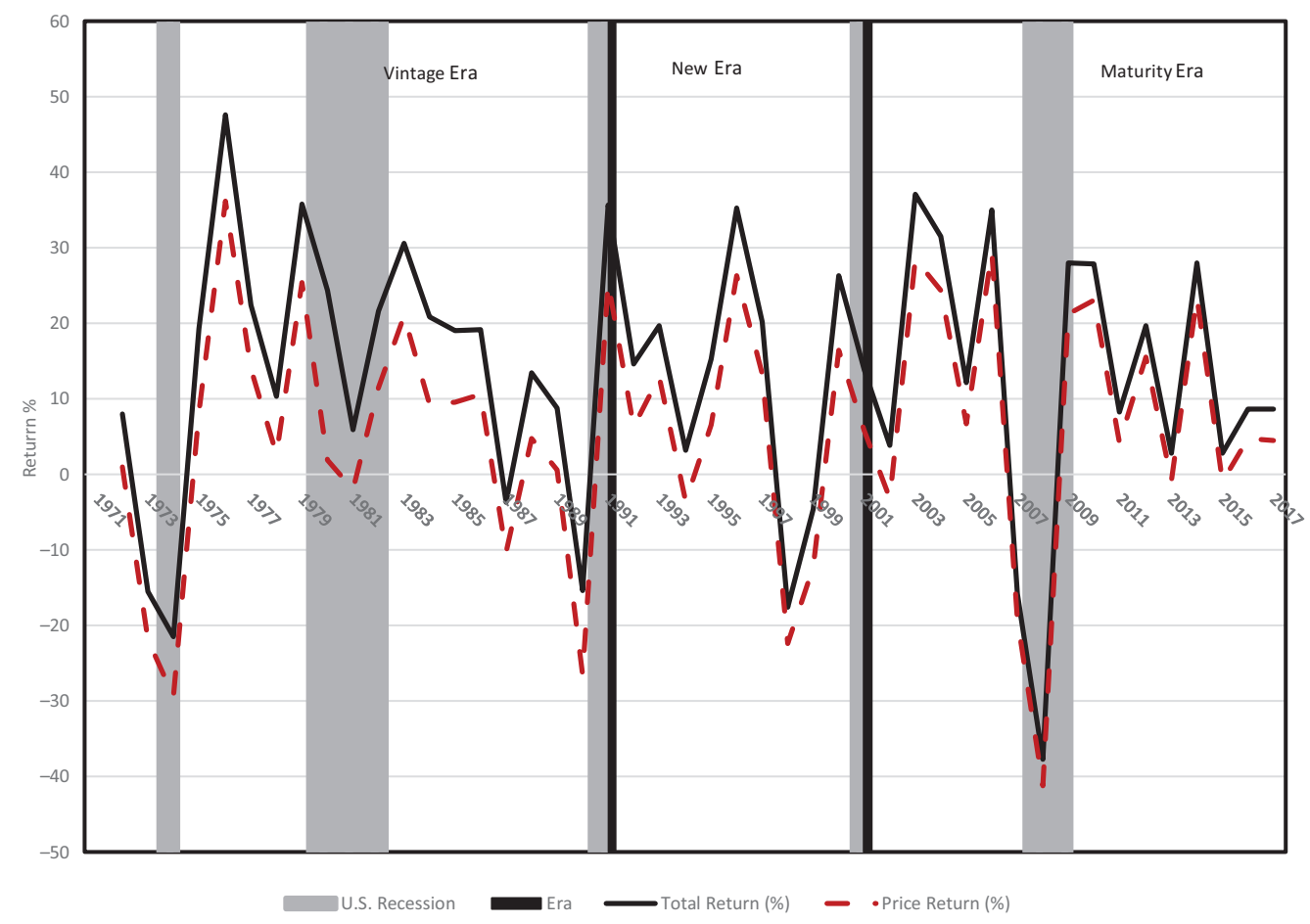

Panel B: Annual total and price returns on the FTSE-NAREIT All Equity REIT Index

Note: This graph illustrates the evolution of the REIT industry in (1) the number of all and Equity REITs, (2) their market valuations, and (3) their return metrics. Data for these graphs are from the National Association of Real Estate Trusts (2020c), https://www.reit.com.

Figure 1. Evolution of the REIT industry, 1971-2017 
our Equity REIT sample proxies for the FTSE NAREIT All Equity Index, our conclusions also relate to this index's performance between 1989 and 2015.

First, the sum of the changes in the industry's ROE over the sample period is $-1.42 \%$. The industry's profitability changes suffer massively under the duress of the GFC between 2007 and 2009. Removing the GFC years of 2007 through 2009 from the sample period boosts this sum to $3.82 \%$. The same sum over the New REIT Era (between 1991 and 2001) is $-1.52 \%$. So, controlling for the GFC's effects moves the industry's cumulative profitability changes from the negative territory, observed in the 1990s, to the positive territory, observed since the first-ever listing of a REIT in the S\&P500 Index in October 2001.

Second, except the GFC years, the improved profitability of individual REITs (i.e., the "within" effect) maintains a positive sum across all periods considered in this paper. Its magnitude more than doubles from the New REIT Era to the REIT Maturity Era. These findings are consistent with our expectations. What surprises us are the results on the shifts of resources from less to more profitable REITs (i.e., the "between" effect). Across the entire sample period, the main sample sub-periods, and the GFC years between 2007 and 2009, the sign of the sum of the annual "between" effects is the opposite of the sign of the sum of the annual "within" effects.

At least three interesting implications arise from this pattern. First, the positive sum of the "between" effect during the GFC years counters partially the massively negative sum in the "within" effect. The "between" effect serves as an endegenous risk management apparatus during this unique period, which has put capitalism's survival into an ongoing debate. Second, the industry appears to prefer not to shift resources from less to more profitable REITs so far. Comparisons of the results between the More- and Less-transparent sub-samples strengthen these conclusions. Our findings may serve as a nudge to the managers of REITs to examine strategies on how to benefit more and better from the "between" effect. Finally, during normal times, REITs experience growth in profitability within the firm and the lower performing REITs do better, on average, than higher performing REITs. But, during abnormal times (i.e., GFC), REITs experience losses of profitability within the firm and higher performing REITs do better than lower performing REITs.

Keeping in mind the constraints of a small sample size on empirical tests, we note that the firm size appears not to influence the industry's profitability changes. We are surprisingly unable to locate any recent study on the economic efficiency of the REIT industry. The observed evidence of diseconomies of scale in this industry comes from cost function specifications from the late 1990s or early 2000s (Ambrose et al., 2000, 2005; Anderson et al., 2002; Miller et al., 2006) and is consistent with a negative sum in the annual changes in ROE during the New REIT Era. Our annual and cumulative results for the REIT Maturity Era, however, hint that improvements in the indus- try's economic efficiency might have occurred. Our results offer inferential and preliminary evidence to fill some of the gap and highlight the need for more research and renewed interest in this area.

This paper unfolds as follows. Section 1 discusses the traditional dynamic decomposition, derives an alternative dynamic decomposition that, when combined with the first decomposition, yields the Bennet dynamic decomposition and puts forth our hypotheses. Section 2 discusses the data and sample. Section 3 provides empirical results. Last section concludes the paper.

\section{Alternative dynamic decompositions ${ }^{6}$}

\subsection{Details of decomposition methodology}

Bailey et al. (1992) provide an algebraic decomposition of an industry's total factor productivity (TFP) growth into three effects - "within," "between," and "net-entry" (entry minus exit) effects. The "within" effect measures the contribution of surviving firms toward TFP growth. The "between (or reallocation)" effect measures the contribution of changing market share of surviving firms toward TFP growth, while the "net-entry" effect measures the contribution of firms' entry into and exit from the industry toward TFP growth. Extending Bailey et al. (1992), Haltiwanger (1997) separates the effects of firm entrants into and exit from the industry. Moreover, he also divides the "between" effect into two components - the "share" and "covariance" effects. The "share" effect measures the contribution toward aggregate TFP growth of the changing share of firms while the "covariance" effect measures the contribution toward aggregate TFP growth of the changing share of firms times the changing TFP growth of firms. Stiroh (2000), using U.S. banking data, further decomposes Haltiwanger's (1997) method by dividing banks into those that acquired other banks and those that did not.

Such decomposition methods share a common indexnumber issue - the base-year choice. Bailey et al. (1992), Haltiwanger (1997), and Stiroh (2000) choose the initial year, $(t-1)$, as the base. Thus, the "within" effect measures the change in TFP growth at the firm level between the initial $(t-1)$ and final $(t)$ years weighted by the initial $(t-1)$ year's market share. Alternatively, another decomposition possibility exists when the final $(t)$ year provides the base. That is, the "within" effect weights the change in TFP growth between $(t-1)$ and $(t)$ for each firm by the firm's industry share in the final $(t)$ year. Finally, the Bennet (1920) decomposition combines these two dynamic decompositions into a simple average. ${ }^{7}$ Thus, the weighting

\footnotetext{
${ }^{6}$ Jeon and Miller (2005) provide details of the derivations.

7 This discussion possesses an analogy to the price index literature. The Laspeyres (1871) price index uses the initial year, the Paasche (1974) price index uses the final year, and the Fisher (1922) ideal price index forms a geometric, rather than arithmetic, average. Pigou (1920) also proposed the ideal price index. Rather than considering a ratio, we focus on the change in ROE.
} 
of the "within," "between," "entry," and "exit" effects all employ simple averages of the initial $(t-1)$ and final $(t)$ year weights. In addition, the Bennet dynamic decomposition eliminates Haltiwanger's (1997) "covariance" effect as it emerges because of the method of decomposition. ${ }^{8}$

Since we apply the Bennet dynamic decomposition to the U.S. REIT industry, our derivation of the various dynamic decompositions employs industry ROE as an illustration. Although we undertake our work based on FFO, our presentation below follows the NI notation since this definition of ROE is more widely known. At time $t$, the ROE $\left(R_{t}\right)$ equals net income, $N I_{t}$, divided by total equity $\left(E_{t}\right)$. That is,

$$
R_{t}=\frac{N I_{t}}{E_{t}}
$$

where: $N I_{t}=\sum_{i=1}^{n_{t}} N I_{i, t} ; E_{t}=\sum_{i=1}^{n_{t}} E_{i, t} ; n_{t}$ is the number of REITs.

After substitution and rearrangement, we get

$$
R_{t}=\sum_{i=1}^{n_{t}} r_{i, t} \theta_{i, t} \text {, }
$$

where: $r_{i, t}$ equals the ratio of NI to E for REIT $i$ in period $t$ and $\theta_{i . t}$ equals the $i$-th REIT's share of industry equity.

We want to decompose the change in industry ROE into "within," "between," "entry," and "exit" effects. The change in industry ROE equals the following:

$$
\Delta R_{t}=R_{t}-R_{t-1}=\sum_{i=1}^{n_{t}} r_{i, t} \theta_{i, t}-\sum_{i=1}^{n_{t-1}} r_{i, t-1} \theta_{i, t-1} .
$$

The number of REITs in period $t$ equals the number of REITS in period $t-1$ plus the number of REIT entrants minus the number of REIT exits. That is,

$$
n_{t}=n_{t-1}+n_{t}^{\text {enter }}-n_{t-1}^{\text {exit }} \text {. }
$$

Rearranging terms in Equation (4) yields

$$
\begin{aligned}
& n_{t}-n_{t}^{\text {enter }}=n_{t-1}-n_{t-1}^{\text {exit }}=n_{t / t-1}^{\text {stay }} \text {; or } \\
& n_{t}=n_{t / t-1}^{\text {stay }}+n_{t}^{\text {enter }} \text {, and } n_{t-1}=n_{t / t-1}^{\text {stay }}+n_{t-1}^{\text {exit }} .9
\end{aligned}
$$

Bennet (1920) specifies the analogy to the Fisher ideal price index for changes in revenue - the sum of prices times quantities. We employ Bennet's approach to the change in the average ROE, which equals the sum of the individual REIT's ROE times that individual REIT's equity share [see Equations (2) and (3)]. Diewert (2005) provides an extensive discussion of the Bennet index, showing that the Bennet index equals the arithmetic average of the Laspeyres and Paasche difference index analogies.

8 Griliches and Regev (1995) employ this decomposition in studying productivity in Israel. Scarpetta et al. (2002) briefly describe the Griliches and Regev (1995) and Haltiwanger (1997) methods of decomposition, noting how they differ. Following Jeon and Miller (2005), we, however, link the differences to the base-year weighting issue. Bartelsman et al. (2004) note that the covariance term disappears for their decomposition. Balk (2003) also provides an extensive review of the Bennet decomposition in terms of productivity changes.

9 Consider two time periods $(t-1)$ and $(t)$. We classify REITs as staying, if the REITs exists in both $(t-1)$ and $(t)$; entering, if the REIT does not exist in $(t-1)$ but does in $(t)$; and exiting, if the REIT exists in $(t-1)$ but not in $(t)$.
Thus, Equation (3) adjusts as follows:

$$
\begin{aligned}
& \Delta R_{t}=\sum_{i=1}^{n_{t / t-1}^{\text {stay }}} r_{i, t} \theta_{i, t}+\sum_{i=1}^{n_{t}^{\text {enter }}} r_{i, t} \theta_{i, t}-\sum_{i=1}^{n_{t / t-1}^{\text {stay }}} r_{i, t-1} \theta_{i, t-1}- \\
& \sum_{i=1}^{n_{t-1}^{\text {exit }}} r_{i, t-1} \theta_{i, t-1} .
\end{aligned}
$$

Case 1: Existing dynamic decomposition - Laspeyres difference index

While we already separate the "stay" terms from the "entry" and "exit" terms, we now need to decompose the "stay" terms into the "within" and "between" effects. Bailey et al. (1992) and Haltiwanger (1997) weight the "within" effect with the individual firm's industry share of equity in the initial year. ${ }^{10}$ That is, we need to add and subtract $\sum_{i=1}^{n_{t t l-1}^{s t a y}} r_{i, t} \theta_{i, t-1}$ from the right-hand side of Equation (7). After some manipulation, we get

$$
\begin{aligned}
& \Delta R_{t}=\sum_{i=1}^{n_{t / t-1}^{\text {stay }}} r_{i, t} \theta_{i, \Delta t}+\sum_{i=1}^{n_{t l t-1}^{\text {stay }}} r_{i, \Delta t} \theta_{i, t-1}+\sum_{i=1}^{n_{t}^{\text {enter }}} r_{i, t} \theta_{i, t}- \\
& \sum_{i=1}^{n_{t-1}^{\text {exit }}} r_{i, t-1} \theta_{i, t-1},
\end{aligned}
$$

where: $\theta_{i, \Delta t}=\theta_{i, t}-\theta_{i, t-1}$ and $r_{i, \Delta t}=r_{i, t}-r_{i, t-1}$.

Then, we can rewrite Equation (8) as follows:

$$
\begin{gathered}
\Delta R_{t}=\sum_{i=1}^{\sum_{t / t-1}^{n_{t}} r_{i, \Delta t}} \theta_{i, t-1}+\sum_{i=1}^{n_{t / t-1}^{\text {stay }}\left(r_{i, t}-R_{t-1}\right) \theta_{i, \Delta t}}+ \\
\text { "within effect" } \\
\sum_{i=1}^{n_{t}^{\text {enter }}}\left(r_{i, t}-R_{t-1}\right) \theta_{i, t}-\sum_{i=1}^{n_{t-1}^{\text {exit }}}\left(r_{i, t-1}-R_{t-1}\right) \theta_{i, t-1}, \\
\text { "entry effect" }
\end{gathered}
$$

where we evaluate the "between," "entry," and "exit" effects relative to the lagged industry $\operatorname{ROE}\left(R_{t-1}\right)$. For example, the "between" effect sums the differences between each REIT's ROE and the industry's ROE, multiplied by that REIT's change in equity share. In this case, we evaluate the REIT's ROE in period $t$ and the industry's ROE in period $t-1 .^{11}$

Case 2: Alternative dynamic decomposition - Paasche difference index

We decompose the change in industry ROE by weighting the "within" effect by period- $t$ individual REIT"s share of industry equity. ${ }^{12}$ In other words, we need to add and subtract $\sum_{i=1}^{n_{t / t-1}^{\text {stay }}} r_{i t-} \theta_{i t}$ to Equation (7). After necessary manipulations, the final form equals:

\footnotetext{
${ }^{10}$ Diewert (2005) calls this the Laspeyres difference index.

${ }^{11}$ Because of the timing difference, Haltiwanger (1997) decomposes the "between (reallocation)" effect into a "share" effect and a "covariance" effect contained in the "between" effect summation. Stiroh (2000) further decomposes the "within," "share," and "covariance" effects into effects for banks that acquire other banks and banks that do not. Our Bennet decomposition also eliminates this problem, as the "covariance" effect disappears.

${ }^{12}$ Diewert (2005) calls this the Paasche difference index.
} 


$$
\begin{gathered}
\Delta R_{t}=\sum_{i=1}^{n_{t / t-1}^{\text {stay }}} r_{i, \Delta t} \theta_{i, t}+\sum_{i=1}^{\sum_{\text {with }}^{n_{t / t} \text { stay }}\left(r_{i, t-1}-R_{t}\right) \theta_{i, \Delta t}+} \\
\text { "between effect" } \\
\sum_{i=1}^{n_{t}^{\text {enter }}}\left(r_{i, t}-R_{t}\right) \theta_{i, t}-\sum_{i=1}^{n_{t-1}^{\text {exit }}\left(r_{i, t-1}-R_{t}\right) \theta_{i, t-1},} \\
\text { "entry effect" }
\end{gathered}
$$

where we evaluate the "between," "entry," and "exit" effects relative to the current industry $\operatorname{ROE}\left(R_{t}\right) .{ }^{13}$

\section{Case 3: Bennet dynamic decomposition}

The Bennet dynamic decomposition computes the arithmetic average of Case 1 and Case 2 as follows: ${ }^{14}$

$$
\begin{aligned}
& \Delta R_{t}=\sum_{i=1}^{n_{t / t-1}^{\text {stay }}} r_{i, \Delta t} \bar{\theta}_{i}+\sum_{i=1}^{n_{t / t-1}^{\text {stay }}\left(r_{i}-\bar{R}\right) \theta_{i, \Delta t}+} \\
& \text { "within effect" "between effect" } \\
& \sum_{i=1}^{n_{t}^{\text {enter }}}\left(r_{i, t}-\bar{R}\right) \theta_{i, t}-\sum_{i=1}^{n_{t-1}^{\text {exit }}}\left(r_{i, t-1}-\bar{R}\right) \theta_{i, t-1}, \\
& \text { "entry effect" "exit effect" }
\end{aligned}
$$

where: $\bar{\theta}_{i}=\left(\theta_{i-t}+\theta_{i t-}\right) / 2, \bar{r}_{i}=\left(r_{i t}+r_{i t-}\right) / 2$, and

$\bar{R}=\left(R_{t}+R_{t-1}\right) / 2$.

The Bennet dynamic decomposition includes four effects. The "within" effect equals the summation of each REIT's change in ROE weighted by its average share of industry equity between period $t-1$ and period $t$. The "between (reallocation)" effect equals the summation of the difference between each REIT's ROE and the average industry ROE between period $t$ and period $t-1$, multiplied by the change in that REIT's share of industry equity. The "entry" effect equals the summation of the difference between each entry REIT's ROE in period $t$ and the average industry ROE between period $t-1$ and period $t$ times the entry REIT's share of industry equity in period $t$. Finally, the "exit" effect equals the summation of the difference between each exit REIT's ROE in period $t-1$ and the average industry ROE between period $t-1$ and period $t$, multiplied by the exit REIT's share of industry equity in period $t-1$.

\subsection{Development of hypotheses}

Schumpeter (1950, Chp VII) coined the phrase "creative destruction" to describe his view of capitalism, evolving through a dynamic process of mergers, entry, and exit of firms spurred by innovation and technical change. Bartelsman et al. (2004) associate the "reallocation (between)," "entry," and "exit" effects of productivity change with creative destruction, which they call restructuring, reallocation, and creative destruction. Further, the authors note that performance differences between the entering and exiting firms will not likely by themselves sufficiently measure the crea-

\footnotetext{
${ }^{13}$ Note, also, that for the between effect, the lagged ROE for each REIT replaces the current ROE between Equations (9) and (10).

${ }^{14}$ See Diewert (2005) for additional details. Jeon and Miller (2005) also provide the derivation.
}

tive destruction contribution since distortions may occur, even simultaneously, in a given country. For example, some policies may treat some incumbents more favorably, others may increase entry barriers, while some others may make exit more likely for some firms (e.g., poorly functioning financial markets for young and small businesses).

On the one hand, high capital intensity and regulatory cash holding requirements to meet the legally mandated periodic dividend payout ratios characterize the REIT industry. Yet, there has been a substantial jump in the firm valuations as well as the investors' interests in the REITs so much so that several countries have adopted the REIT structure since the late 1990s. So, the public must maintain its confidence in the soundness of the REIT industry. A process of creative destruction in the REIT industry, if too large, may undermine the public's confidence. Since stability is a hallmark of a sound REIT industry and some of the surviving REITs have grown considerably, dominating the sector over time, we postulate that the "within" effect, i.e., the temporal growth of surviving REITs, should be the dominant component of the annual movements in aggregate REIT performance.

On the other hand, Figure 1 shows the movement in the number of REITs -- increases from the middle of 1980s until the early 1990s, declines from the mid-1990s until mid-2000s, and then increases once again since mid2000s. Eyeballing the temporal market valuations of REITs since the late 1990s indicates the considerable growth in the size of some of the sample REITs, backed by inclusion in the S\&P indices starting with October 2001. These patterns lead us to postulate that the "reallocation or between" effect should be the dominant component of the annual movements in aggregate REIT performance.

We do not possess any a priori reason to expect that the "within" effect will dominate the "between" effect (or vice versa). This remains an empirical matter.

Now we consider how the component effects associate with the REIT industry specific sub-periods. We expect that the "within" effect should dominate the "between" effect during the New REIT Era. This is the period that witnessed the temporal growth of the REITs in response to the (1) then-newly introduced sector-specific regulatory incentives and (2) substantially enhanced access to the capital markets through embracing the rules set by the Wall Street establishment.

The indeterminacy, as just expressed above for the entire sample period, between the "within" versus "between" effects extends itself into other sub-period examinations. Once again, we do not have any a priori reason to expect that the "within" effect will dominate the "between" effect (or vice versa) during the REIT Maturity Era and that the "within" and "between" effects of the New REIT Era will differ from their counterparts of the REIT Maturity Era. All these time-dependent differences also remain an empirical matter.

Focusing individually on either the More-transparent or the Less-transparent REIT sub-sample leads to the same conjectures about the temporal behavior of the 
"within" and "between" effects, as just explained for the entire sample above. Meanwhile, considering comparatively the More- and Less-transparent sub-samples offers the conjecture that both the "within" and "between" effects of the More-transparent sub-sample of REITs should dominate their counterparts of the Less-transparent subsample of REITs.

We also postulate that concentration should influence positively the REIT industry's aggregated profitability. This follows from the observation that a few number of REITs had grown quite a bit in the time period leading up to the first REIT listing in the S\&P500 Index in early October 2001, opening the door for the beginning of the REIT Maturity Era.

\section{Data and sample}

We build our database by merging distinct variables with annual frequency available in the COMPUSTAT, supplemented to the extent possible, by CRSP/ZIMAN databases and as compiled and kindly provided to us by NAREIT. ${ }^{15}$ When a variable does not appear in these sources or contains several missing values, data collected from either
Internet searches or the EDGAR database enter into our own database. Our FFO-based (NI-based) sample covers the Equity REITs that report no negative values between 1989 and 2015 (1980-2015), respectively. Feng et al.s (2011) classification of REITs, especially between 1993 and 2015, guides us in identifying the sample firms. Further, we restrict the sample firms' ROE to fall between $-100 \%$ to $100 \%$ to avoid the distortions due to outliers and report annually both equally weighted, EW, and total equity weighted, TEQW, industry ROEs. There are a total of 33 observations (= 18 less than $-100 \%$ plus 15 higher than $100 \%$ ) deleted from our sample due to this restriction. That is less than $1 \%$ of the total number of 3,888 observations in our sample.

Despite our efforts to build a comprehensive database, missing data to construct ROE remain an obstacle and reduce our sample size. We provide a comprehensive analysis of the evolution of our sample and sub-samples by decomposition categories and annually across the sample period in the Results section below.

Panels A and B of Table 1 tabulate the descriptive statistics for our key variables of FFO, TA, TE, and ROE (FFO-based) $=\mathrm{FFO} / \mathrm{TE}$ (and to be comprehensive, also NI, and ROE (NI-based) $=$ NI/TE) by sample year and

Table 1. Annual means and standard deviations of sample REITs' net income, funds from operations, total assets, total equity, and ROE, during the sample period of 1989-2015

Panel A: Net income, funds from operations, total assets and total equity

\begin{tabular}{|c|c|c|c|c|c|c|c|c|c|c|c|c|}
\hline \multirow{2}{*}{ Year } & \multicolumn{3}{|c|}{ Net income (\$Million) } & \multicolumn{3}{|c|}{$\begin{array}{c}\text { Fund from } \\
\text { operations (\$Million) }\end{array}$} & \multicolumn{3}{|c|}{ Total assets (\$Million) } & \multicolumn{3}{|c|}{ Total equity (\$Million) } \\
\hline & $\begin{array}{l}\text { No. of } \\
\text { REITs }\end{array}$ & Mean & Std. Dev. & $\begin{array}{l}\text { No. of } \\
\text { REITs }\end{array}$ & Mean & Std. Dev. & $\begin{array}{l}\text { No. of } \\
\text { REITs }\end{array}$ & Mean & Std. Dev. & $\begin{array}{l}\text { No. of } \\
\text { REITs }\end{array}$ & Mean & Std. Dev. \\
\hline 1989 & 51 & 1.700 & 20.356 & 19 & 11.111 & 8.298 & 51 & 156.573 & 132.722 & 51 & 84.630 & 63.682 \\
\hline 1990 & 53 & 3.600 & 13.442 & 20 & 11.505 & 9.664 & 53 & 161.138 & 138.389 & 53 & 81.383 & 62.878 \\
\hline 1991 & 73 & 3.301 & 10.177 & 41 & 9.888 & 11.352 & 73 & 142.953 & 141.187 & 73 & 79.068 & 69.683 \\
\hline 1992 & 76 & 3.157 & 11.271 & 51 & 10.560 & 11.574 & 76 & 161.904 & 160.836 & 76 & 85.822 & 91.075 \\
\hline 1993 & 128 & 5.127 & 12.024 & 90 & 14.845 & 15.075 & 128 & 252.215 & 250.424 & 128 & & 130.204 \\
\hline 1994 & 167 & & & 134 & 20.870 & & 167 & & & 167 & & 159.877 \\
\hline 1995 & 167 & & & 144 & 29.043 & 28.628 & 167 & & & 167 & & 234.198 \\
\hline 1996 & 158 & 20.621 & 25.925 & 137 & 40.546 & 41.294 & 158 & 606.912 & 672.788 & 158 & 310.996 & 357.428 \\
\hline 1997 & 170 & 29.554 & 33.606 & 151 & 57.262 & 62.121 & 170 & 1026.730 & 1345.200 & 170 & 546.402 & 764.011 \\
\hline 1998 & 174 & 45.593 & 107.848 & 152 & 90.571 & 117.005 & 174 & 1597.270 & 2320.180 & 174 & 744.652 & 1055.080 \\
\hline 1999 & 167 & 43.132 & 127.810 & 143 & 106.864 & 125.877 & 167 & 1764.170 & 2347.770 & 167 & 819.029 & 1096.840 \\
\hline 2000 & 153 & 59.134 & 94.287 & 131 & 119.197 & 149.362 & 153 & 1821.290 & 2493.310 & 153 & 826.394 & 1179.050 \\
\hline 2001 & 144 & 52.424 & 96.478 & 124 & 118.744 & 163.664 & 144 & 1914.690 & 2941.280 & 144 & 876.034 & 1429.000 \\
\hline 2002 & 138 & 58.372 & 121.291 & 116 & 129.722 & 194.187 & 138 & 2211.650 & 3169.230 & 138 & 962.000 & 1450.790 \\
\hline 2003 & 140 & 72.527 & 128.152 & 119 & 129.241 & 191.007 & 140 & 2347.180 & 3119.380 & 140 & 1011.310 & 1405.880 \\
\hline 2004 & 149 & 71.539 & 111.244 & 126 & 129.841 & 181.839 & 149 & 2540.430 & 3849.180 & 149 & 1008.820 & 1399.990 \\
\hline 2005 & 150 & 79.152 & 140.470 & 128 & 130.104 & 190.651 & 150 & 2752.380 & 3909.700 & 150 & 1045.830 & 1384.560 \\
\hline 2006 & 129 & 116.456 & 189.894 & 112 & 173.453 & 243.306 & 129 & 3486.550 & 4604.300 & 129 & 1327.590 & 1693.730 \\
\hline 2007 & 116 & 134.000 & 221.500 & 108 & 202.652 & 285.796 & 116 & 3834.080 & 4902.030 & 116 & 1361.650 & 1637.620 \\
\hline
\end{tabular}

${ }^{15}$ We thank Brad Case for kindly providing us with data from NAREIT's resources, Erkan Yonder for helping us in identifying and collecting some of our data from various sources, and Steve Cauley for his comments that guided us in cross checking our data vis-a-via the CRSP/ZIMAN database. 
End of Table 1

\begin{tabular}{|c|c|c|c|c|c|c|c|c|c|c|c|c|}
\hline \multirow{2}{*}{ Year } & \multicolumn{3}{|c|}{ Net income (\$Million) } & \multicolumn{3}{|c|}{$\begin{array}{c}\text { Fund from } \\
\text { operations (\$Million) }\end{array}$} & \multicolumn{3}{|c|}{ Total assets (\$Million) } & \multicolumn{3}{|c|}{ Total equity (\$Million) } \\
\hline & $\begin{array}{l}\text { No. of } \\
\text { REITs }\end{array}$ & Mean & Std. Dev. & $\begin{array}{l}\text { No. of } \\
\text { REITs }\end{array}$ & Mean & Std. Dev. & $\begin{array}{l}\text { No. of } \\
\text { REITs }\end{array}$ & Mean & Std. Dev. & $\begin{array}{l}\text { No. of } \\
\text { REITs }\end{array}$ & Mean & Std. Dev. \\
\hline 2008 & 112 & 82.295 & 165.122 & 105 & 184.293 & 264.255 & 112 & 3875.590 & 4868.430 & 112 & 1362.560 & 1593.290 \\
\hline 2009 & 110 & 24.430 & 153.293 & 104 & 146.635 & 241.555 & 110 & 3625.980 & 4206.450 & 110 & 1468.160 & 1786.590 \\
\hline 2010 & 120 & 31.283 & 249.513 & 113 & 152.056 & 279.079 & 120 & 3907.350 & 4921.910 & 120 & 1633.790 & 2007.640 \\
\hline 2011 & 122 & 74.920 & 187.159 & 116 & 200.076 & 317.337 & 122 & 4151.470 & 5442.460 & 122 & 1776.660 & 2389.220 \\
\hline 2012 & 130 & 96.143 & 213.904 & 125 & 229.032 & 359.821 & 130 & 4501.030 & 5751.930 & 130 & 1934.300 & 2473.240 \\
\hline 2013 & 154 & 112.724 & 242.169 & 146 & 234.738 & 371.928 & 154 & 4511.260 & 5803.320 & 154 & 2007.490 & 2564.980 \\
\hline 2014 & 169 & 142.029 & 297.558 & 157 & 270.122 & 399.221 & 169 & 4869.580 & 5986.000 & 169 & 2150.670 & 2672.330 \\
\hline 2015 & 165 & 155.950 & 311.953 & 152 & 298.064 & 431.225 & 165 & 5362.690 & 6357.260 & 165 & 2351.990 & 2916.990 \\
\hline All & 3855 & 57.248 & 158.649 & 3064 & 134.058 & 246.527 & 3855 & 2256.880 & 3971.750 & 3855 & 962.182 & 1676.870 \\
\hline
\end{tabular}

Panel B: ROE based on net income or funds from operations

\begin{tabular}{|c|c|c|c|c|c|c|c|c|}
\hline \multirow[b]{2}{*}{ Year } & \multirow[b]{2}{*}{ No of REITs } & \multicolumn{3}{|c|}{ ROE(\%) - NI-based } & \multirow[b]{2}{*}{ No of REITs } & \multicolumn{3}{|c|}{$\mathrm{ROE}(\%)$ - FFO-based } \\
\hline & & EW-Mean & Std. Dev. & $\begin{array}{l}\text { TEQW- } \\
\text { Mean }\end{array}$ & & EW-Mean & Std. Dev. & $\begin{array}{l}\text { TEQW- } \\
\text { Mean }\end{array}$ \\
\hline 1989 & 51 & 0.129 & 20.851 & 0.637 & 19 & 11.495 & 6.682 & 11.815 \\
\hline 1990 & 53 & 2.762 & 15.059 & 2.158 & 20 & 11.804 & 6.824 & 12.967 \\
\hline 1991 & 73 & 2.343 & 14.680 & 3.779 & 41 & 9.998 & 7.349 & 10.751 \\
\hline 1992 & 76 & 1.324 & 18.013 & 3.958 & 51 & 9.550 & 5.762 & 10.463 \\
\hline 1993 & 128 & 2.189 & 14.946 & 3.811 & 90 & 10.111 & 7.891 & 9.530 \\
\hline 1994 & 167 & 5.453 & 12.821 & 5.876 & 134 & 14.542 & 14.535 & 11.648 \\
\hline 1995 & 167 & 5.247 & 11.626 & 6.470 & 144 & 15.300 & 15.467 & 12.618 \\
\hline 1996 & 158 & 6.623 & 7.982 & 6.640 & 137 & 13.790 & 8.482 & 11.782 \\
\hline 1997 & 170 & 6.544 & 6.758 & 5.440 & 151 & 11.668 & 8.016 & 9.851 \\
\hline 1998 & 174 & 4.621 & 10.693 & 6.071 & 152 & 14.939 & 19.981 & 11.396 \\
\hline 1999 & 167 & 7.295 & 9.511 & 5.397 & 143 & 22.082 & 84.668 & 12.623 \\
\hline 2000 & 153 & 7.811 & 15.205 & 7.404 & 131 & 15.694 & 15.493 & 13.386 \\
\hline 2001 & 144 & 3.573 & 16.247 & 5.578 & 124 & 17.098 & 32.907 & 12.621 \\
\hline 2002 & 138 & 4.167 & 13.199 & 6.148 & 116 & 13.561 & 9.536 & 12.581 \\
\hline 2003 & 140 & 4.995 & 11.230 & 7.381 & 119 & 13.999 & 26.412 & 12.344 \\
\hline 2004 & 149 & 6.987 & 11.287 & 7.190 & 126 & 11.847 & 14.909 & 12.219 \\
\hline 2005 & 150 & 5.869 & 13.315 & 7.588 & 128 & 12.881 & 14.505 & 11.825 \\
\hline 2006 & 129 & 7.860 & 8.807 & 8.768 & 112 & 11.956 & 21.591 & 12.423 \\
\hline 2007 & 116 & 7.789 & 11.895 & 9.924 & 108 & 20.373 & 48.426 & 14.774 \\
\hline 2008 & 112 & 6.424 & 12.632 & 6.039 & 105 & 14.004 & 13.031 & 12.760 \\
\hline 2009 & 110 & 3.684 & 16.978 & 2.141 & 104 & 8.633 & 16.545 & 9.386 \\
\hline 2010 & 120 & 1.301 & 10.163 & 1.935 & 113 & 8.827 & 10.597 & 8.975 \\
\hline 2011 & 122 & 1.370 & 12.262 & 4.070 & 116 & 10.431 & 7.697 & 10.786 \\
\hline 2012 & 130 & 2.619 & 10.841 & 5.001 & 125 & 11.246 & 8.361 & 11.508 \\
\hline 2013 & 154 & 3.862 & 10.500 & 5.576 & 146 & 11.178 & 9.169 & 11.601 \\
\hline 2014 & 169 & 4.373 & 12.209 & 6.745 & 157 & 12.352 & 12.794 & 12.309 \\
\hline 2015 & 165 & 4.976 & 11.810 & 6.606 & 152 & 14.054 & 17.200 & 12.914 \\
\hline All & 3855 & 5.332 & 12.597 & 6.993 & 3064 & 13.452 & 25.235 & 11.773 \\
\hline
\end{tabular}

Note: We construct our sample mainly from COMPUSTAT data, supplemented by the CRSP/Ziman and EDGAR databases and various internet searches. We restrict each firm's ROE to fall between $-100 \%$ to $100 \%$ where ROE $=\mathrm{NI} / \mathrm{TE}$ or ROE $=\mathrm{FFO} / \mathrm{TE}$ by each sample year. To calculate the Bennet dynamic decomposition between two years, say 1999 and 2000, we need to identify and separate entrants (REITs that entered the industry), exits (REITs that exited the industry or converted to private ownership), and stays (REITs that stayed in the industry). To do so, we matched REIT ID numbers and tickers in our merged database. If a REIT ID number or ticker exists in both 1999 and 2000, then the REIT stays in the industry. If a REIT ID number or ticker exists in 1999, but not in 2000, then the REIT exits. If a REIT ID number or ticker exists in 2000, but not in 1999, then the REIT enters. In Panel B, EW and TEQW indicate equally weighted and total equity weighted, respectively. The EW- and TEQW-based ROE values follow from Equation (2) and refer to the industry level ROE (e.g., for NI-based industry ROE in a given sample year = Sum of net income across all sample REITs/Sum of their total equity). 
for the entire sample period. Panels A and B of Figure 1 provide the evolution of the FTSE NAREIT All Equity REIT series' (1) annual number of REITs and their yearend market values for the entire sample and (2) the total return and price return series between 1971 and 2017.

Data for OLS estimations come from NAREIT for the annual total market capitalization of Equity REITs and the annual number of Equity REITs, Jay Ritter's website (2020) for the annual number of IPOs (https://site.warrington.ufl. edu/ritter/ipo-data/), and COMPUSTAT for HHI.

To calculate the dynamic decomposition between two years, say 1999 and 2000, we need to identify and separate entrants (REITs that entered the industry), exits (REITs that exited the industry or converted to private ownership), and stays (REITs that stayed in the industry). To do so, we matched REIT ID numbers and tickers in our merged database. If a REIT ID number or ticker exists in both 1999 and 2000, then the REIT stays in the industry. If a REIT ID number or ticker exists in 1999, but not in 2000 , then the REIT exits. If a REIT ID number or ticker exists in 2000, but not in 1999, then the REIT enters. Table 2 provides the number of REITs for each category for the (1) full NAREIT sample in the industry, (2) our sample of REITs, and (3) and (4), our sub-samples of Moretransparent (Less-transparent) REITs, respectively, where, following Chen et al. (2012), Equity REIT sub-sectors of Apartments, Industrials, Offices, Regional Malls and Shopping Centers (all remaining Equity REIT sub-sectors) are components of the More-transparent (Less-transparent) sub-sample, respectively.

Table 2. Evolution of the number of sample REITs for the entire sample and various sub-samples

\begin{tabular}{|c|c|c|c|c|c|c|c|c|c|c|c|c|}
\hline \multirow[b]{2}{*}{ Time period } & \multicolumn{3}{|c|}{$\begin{array}{l}\text { All publicly traded REITs: } \\
\text { No of REITs in each } \\
\text { component }\end{array}$} & \multicolumn{3}{|c|}{$\begin{array}{l}\text { Sample REITs: No of REITs } \\
\text { in each component }\end{array}$} & \multicolumn{3}{|c|}{$\begin{array}{l}\text { More-transparent sub- } \\
\text { sample: No of REITs in } \\
\text { each component }\end{array}$} & \multicolumn{3}{|c|}{$\begin{array}{l}\text { Less-transparent sub- } \\
\text { sample: No of REITs in } \\
\text { each component }\end{array}$} \\
\hline & Enter & Stay & Exit & Enter & Stay & Exit & Enter & Stay & Exit & Enter & Stay & Exit \\
\hline $1989-1990$ & 1 & 71 & 1 & 1 & 52 & 0 & 1 & 19 & 0 & 0 & 33 & 0 \\
\hline 1990-1991 & 20 & 71 & 1 & 20 & 53 & 0 & 3 & 20 & 0 & 17 & 33 & 0 \\
\hline 1991-1992 & 4 & 88 & 3 & 3 & 73 & 0 & 3 & 23 & 0 & 0 & 50 & 0 \\
\hline $1992-1993$ & 55 & 88 & 4 & 53 & 75 & 0 & 35 & 26 & 0 & 18 & 49 & 0 \\
\hline 1993-1994 & 47 & 140 & 3 & 47 & 120 & 1 & 28 & 60 & 1 & 19 & 60 & 0 \\
\hline 1994-1995 & 14 & 180 & 7 & 13 & 154 & 1 & 5 & 81 & 1 & 8 & 73 & 0 \\
\hline 1995-1996 & 8 & 184 & 10 & 8 & 150 & 4 & 4 & 81 & 1 & 4 & 69 & 3 \\
\hline 1996-1997 & 27 & 173 & 19 & 26 & 144 & 0 & 18 & 78 & 0 & 8 & 66 & 0 \\
\hline $1997-1998$ & 23 & 183 & 17 & 21 & 153 & 1 & 12 & 87 & 0 & 9 & 66 & 1 \\
\hline 1998-1999 & 7 & 184 & 22 & 7 & 160 & 5 & 0 & 91 & 1 & 7 & 69 & 4 \\
\hline 1999-2000 & 5 & 173 & 18 & 5 & 148 & 7 & 3 & 79 & 4 & 2 & 69 & 3 \\
\hline $2000-2001$ & 6 & 165 & 13 & 6 & 138 & 3 & 1 & 74 & 2 & 5 & 64 & 1 \\
\hline 2001-2002 & 7 & 157 & 14 & 7 & 131 & 3 & 3 & 67 & 2 & 4 & 64 & 1 \\
\hline $2002-2003$ & 10 & 157 & 7 & 9 & 131 & 1 & 5 & 69 & 1 & 4 & 62 & 0 \\
\hline $2003-2004$ & 21 & 153 & 14 & 21 & 128 & 4 & 7 & 69 & 0 & 14 & 59 & 4 \\
\hline 2004-2005 & 13 & 160 & 14 & 13 & 137 & 3 & 4 & 69 & 1 & 9 & 68 & 2 \\
\hline $2005-2006$ & 4 & 160 & 13 & 4 & 125 & 3 & 1 & 63 & 0 & 3 & 62 & 3 \\
\hline $2006-2007$ & 3 & 145 & 19 & 3 & 113 & 3 & 0 & 57 & 0 & 3 & 56 & 3 \\
\hline $2007-2008$ & 2 & 125 & 23 & 2 & 110 & 0 & 1 & 53 & 0 & 1 & 57 & 0 \\
\hline $2008-2009$ & 2 & 120 & 7 & 2 & 108 & 4 & 0 & 51 & 3 & 2 & 57 & 1 \\
\hline 2009-2010 & 12 & 122 & 0 & 12 & 108 & 0 & 6 & 50 & 0 & 6 & 58 & 0 \\
\hline $2010-2011$ & 9 & 133 & 1 & 9 & 113 & 1 & 3 & 54 & 0 & 6 & 59 & 1 \\
\hline $2011-2012$ & 11 & 139 & 3 & 10 & 120 & 1 & 4 & 56 & 0 & 6 & 64 & 1 \\
\hline $2012-2013$ & 28 & 148 & 2 & 26 & 128 & 0 & 9 & 60 & 0 & 17 & 68 & 0 \\
\hline 2013-2014 & 18 & 170 & 6 & 16 & 153 & 1 & 7 & 69 & 0 & 9 & 84 & 1 \\
\hline $2014-2015$ & 20 & 186 & 2 & 17 & 148 & 0 & 6 & 62 & 0 & 11 & 86 & 0 \\
\hline
\end{tabular}

Note: We construct our sample mainly from COMPUSTAT data, supplemented by the CRSP/Ziman and EDGAR databases and various interest searches. We restrict each firm's ROE to fall between $-100 \%$ to $100 \%$. To calculate the Bennet dynamic decomposition between two years, say 1999 and 2000 , we need to identify and separate entrants (REITs that entered the industry), exits (REITs that exited the industry or converted to private ownership), and stays (REITs that stayed in the industry). To do so, we matched REIT ID numbers and tickers in our merged database. If a REIT ID number or ticker exists in both 1999 and 2000, then the REIT stays in the industry. If a REIT ID number or ticker exists in 1999, but not in 2000, then the REIT exits. If a REIT ID number or ticker exists in 2000, but not in 1999, then the REIT enters. We follow Chen et al. (2012) and group sample Equity REITs that invest in apartments, industrials, offices, regional malls, and shopping centers as the More-transparent subset, and group all other Equity REITs as the Less-transparent sub-sample. 
For clarity of the ensuing presentation in the light of the information above, it is useful to highlight the sequential REIT periods and some of their sub-periods, over which we study the REIT industry's annual ROE changes:

a) Vintage Period: 1989-1990;

b) New REIT Era: 1990-1991 through 2000-2001;

c) REIT Maturity Era: 2001-2002 through 2014-2015;

1) Initial REIT Maturity Era: 2001-2002 through 2006-2007;

2) REIT Maturity Era without GFC: 2001-2002 through 2006-2007 and 2009-2010 through 2014-2015; d) GFC-I: 2007-2008;

e) GFC-II: 2007-2008 and 2008-2009.

\section{Results}

Table 3 and Figure 2 provide the annual evolution of each Bennet effect and the "change in ROE" during our sample period. An eyeballing of the time paths in Figure 2 suggests that the "within" effect follows overall the "change in ROE."

Table 3. Evolution of the Bennet dynamic decomposition, funds from operations-based ROE changes: 1989-2015

\begin{tabular}{|c|c|c|c|c|c|}
\hline Years & Within & Between & Entry & Exit & $\triangle \mathrm{ROE}$ \\
\hline 1989-1990 & 0.0132 & 0.0010 & -0.0027 & 0.0000 & 0.0115 \\
\hline 1990-1991 & -0.0117 & 0.0008 & -0.0111 & 0.0000 & -0.0220 \\
\hline 1991-1992 & -0.0076 & 0.0020 & -0.0035 & 0.0000 & -0.0090 \\
\hline $1992-1993$ & -0.0043 & -0.0040 & -0.0040 & 0.0000 & -0.0123 \\
\hline 1993-1994 & 0.0311 & -0.0057 & -0.0044 & 0.0000 & 0.0211 \\
\hline 1994-1995 & 0.0046 & 0.0030 & -0.0014 & 0.0000 & 0.0062 \\
\hline 1995-1996 & -0.0101 & 0.0041 & -0.0028 & -0.0002 & -0.0086 \\
\hline 1996-1997 & -0.0058 & -0.0068 & -0.0090 & 0.0000 & -0.0216 \\
\hline 1997-1998 & 0.0133 & 0.0010 & 0.0008 & 0.0000 & 0.0151 \\
\hline 1998-1999 & 0.0149 & -0.0006 & 0.0003 & -0.0009 & 0.0155 \\
\hline 1999-2000 & 0.0086 & -0.0010 & 0.0003 & 0.0002 & 0.0077 \\
\hline $2000-2001$ & -0.0050 & -0.0016 & -0.0001 & 0.0004 & -0.0071 \\
\hline $2001-2002$ & 0.0006 & 0.0018 & -0.0027 & -0.0004 & 0.0001 \\
\hline $2002-2003$ & -0.0041 & 0.0017 & -0.0004 & 0.0000 & -0.0028 \\
\hline $2003-2004$ & -0.0006 & 0.0031 & -0.0025 & -0.0001 & 0.0000 \\
\hline 2004-2005 & -0.0023 & 0.0015 & -0.0020 & 0.0001 & -0.0029 \\
\hline $2005-2006$ & 0.0064 & -0.0019 & -0.0013 & 0.0000 & 0.0032 \\
\hline 2006-2007 & 0.0194 & -0.0042 & -0.0024 & -0.0006 & 0.0134 \\
\hline $2007-2008$ & -0.0183 & -0.0003 & 0.0000 & 0.0000 & -0.0186 \\
\hline 2008-2009 & -0.0346 & 0.0049 & -0.0001 & 0.0039 & -0.0337 \\
\hline 2009-2010 & -0.0013 & -0.0002 & -0.0026 & 0.0000 & -0.0042 \\
\hline 2010-2011 & 0.0238 & -0.0044 & -0.0009 & -0.0004 & 0.0188 \\
\hline 2011-2012 & 0.0055 & 0.0000 & 0.0013 & -0.0003 & 0.0070 \\
\hline 2012-2013 & 0.0057 & -0.0022 & -0.0028 & 0.0000 & 0.0007 \\
\hline 2013-2014 & 0.0131 & -0.0079 & 0.0006 & 0.0000 & 0.0059 \\
\hline $2014-2015$ & 0.0047 & -0.0022 & 0.0001 & 0.0000 & 0.0026 \\
\hline
\end{tabular}

Note: The change in ROE between any two years equals the sum of the Within, Between, and Entry effects minus the Exit effect. Stay, Enter, and Exit refer to the number of REITs that stay, enter, and exit for each of the two-year pairs. In Panels B, C and D, the Vintage Period-89/90, the New REIT Era, the Initial REIT Maturity Era, the REIT Maturity Era, the REIT Maturity Era without GFC, GFC-I and GFC-II cover the cumulative of the results for each component for the sample years (1) (1990 minus 1989), (2) (1991 minus 1990) through (2001 minus 2000), (3) (2002 minus 2001) through (2007 minus 2006), (4) (2002 minus 2001) through (2015 minus 2014), (5) [(2002 minus 2001) through (2007 minus 2006)] \& [(2010 minus 2009) through (2015 minus. 2014)], (6) (2008 minus 2007), and (7) (2008 minus 2007) \& (2009 minus 2008), respectively. The More-transparent sub-sample includes Equity REITs with investment focus on apartments, industrials, offices, regional malls, and shopping centers. The Less-transparent sub-sample includes all other Equity REITs. 


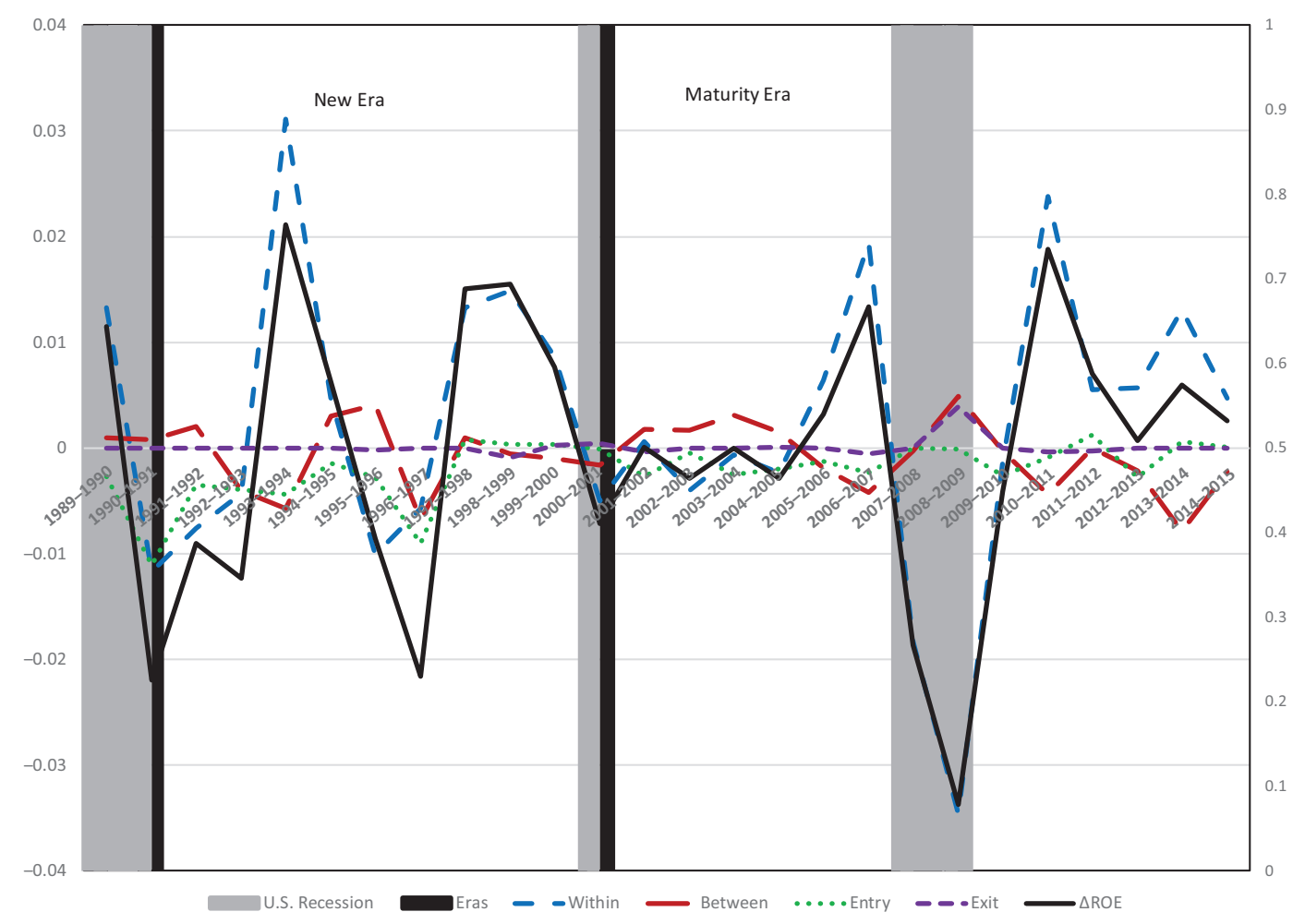

Note: This graph illustrates the annual evolution of each of the "within," "between," "entry," and "exit" effects on the annual "changes in the REIT industry's ROE." The illustrated effects are based on our own computations and empirical work.

Figure 2. Evolution of the Bennet decomposition effects, 1989-2015

\subsection{Estimates of the Bennet effects ${ }^{16}$}

Panels A, B and C of Table 4 provide summary statistics on each Bennet decomposition effect for the Full sample, the More-transparent sub-sample, and the Less-transparent sub-sample, respectively. A closer look at the tabulated results across the panels demonstrates GFC's considerable adverse influences on all Bennet effects as well as the "change in ROE." GFC's effects tend to be visibly more pronounced on the More-transparent sub-sample in Panel $\mathrm{B}$ and on the "within" effect across all panels. Overall, our results suggest a dominant role for the "within" effect during the entire sample period and demonstrates the breathtaking adverse consequences of the GFC.

In Panel A, the sum of "changes in ROE" over the entire sample period is $-1.42 \%$. The "within" effect, with a sum of $5.92 \%$, dominates the other components. The corresponding sums for the "between" and "entry" effects are $-1.83 \%$ and $-5.31 \%$, respectively. A removal of the GFC

\footnotetext{
${ }^{16}$ The FFO-based results differ substantially in magnitude and signs from their unreported NI-based counterparts. The sums of NI-based "change in ROE," "within," "between," "entry" and "exit" effects are $-4.79 \%,-2.48 \%, 9.65 \%,-5.06 \%$ and $-2.68 \%$ respectively. Further, the GFC's erosions on the FFObased measurements are similar to their unreported NI-based counterparts for the More- transparent sub-sample. They are, however, much more significant for the Less-transparent subsample.
}

years generates sums (1) for the entire sample period, of $3.83 \%$ for the "change in ROE" and $11.21 \%,-2.27 \%$, and $-5.32 \%$ for the "within," "between," and "entry," effects and (2) for the REIT Maturity Era, of $4.18 \%$ for the "change in ROE" and $7.09 \%,-1.50 \%$ and $-1.57 \%$ for the "within," "between," and "entry" effects, respectively.

A comparison of the effect-by-effect temporal sums between the More- and Less transparent sub-samples, presented in Panels B and C, demonstrates considerable differences in the magnitudes and signs of all, especially the "within" and "between," effects. While many sums of the "within" effect of the More-transparent sub-sample are mainly positive, the corresponding sums of the "between" effect are mainly negative. Further, the magnitudes of the temporal sums, in absolute value, of the "within" ("between") effect are visibly larger for the More-transparent (Less-transparent) sub-sample than the Less-transparent (More-transparent) sub-sample, respectively.

The estimates of the "between" effect are mostly negative for both the Full sample and the More-transparent sub-sample. They attain positive values for the Less-transparent sub-sample. The More-transparent REITs tend to have easier access to the resources of the capital markets. This unexpected outcome in the "between" effects in favor of the Less-transparent sub-sample hints that REITs in the More-transparent sub-sample tend to miss the optimal timing for restructuring their asset portfolios and/or exiting from the industry. 
Table 4. Evolution of the Bennet dynamic decomposition, funds from operations based ROE: 1989-2015

Panel A: Cumulative; full sample; entire sample period and REIT sub-period results

\begin{tabular}{|l|c|c|c|c|c|}
\hline \multicolumn{1}{|c|}{ REIT period } & Within & Between & Entry & Exit & $\Delta$ ROE \\
\hline Full Sample, Sum & 5.9227 & -1.8293 & -5.3139 & 0.1981 & -1.4186 \\
\hline Full Sample, Average & 0.2278 & -0.0704 & -0.2044 & 0.0076 & -0.0546 \\
\hline Vintage Period-89/90, Sum & 1.3236 & 0.0981 & -0.2694 & 0.0000 & 1.1522 \\
\hline New REIT Era, Sum & 2.7967 & -0.8845 & -3.4664 & -0.0376 & -1.5166 \\
\hline Initial REIT Maturity Era, Sum & 1.9367 & 0.1919 & -1.1266 & -0.0925 & 1.0945 \\
\hline REIT Maturity Era, Sum & 1.8024 & -1.0429 & -1.5781 & 0.2357 & -1.0543 \\
\hline REIT Maturity Era (w/o GFC-II), Sum & 7.0891 & -1.4987 & -1.5674 & -0.1592 & 4.1823 \\
\hline GFC-I, Sum & -1.8298 & -0.0326 & 0.0000 & 0.0000 & -1.8624 \\
\hline GFC-II, Sum & -5.2867 & 0.4557 & -0.0107 & 0.3949 & -5.2366 \\
\hline Year Pair Count: Positive \& Negative & $14 \& 12$ & $12 \& 14$ & $7 \& 19$ & $18 \& 8$ & $14 \& 12$ \\
\hline
\end{tabular}

Panel B: Cumulative; the more-transparent sub-sample; entire sample period and REIT sub-period results

\begin{tabular}{|l|c|c|c|c|c|}
\hline \multicolumn{1}{|c|}{ REIT period } & Within & Between & Entry & Exit & $\Delta$ ROE \\
\hline Full Sample, Sum & 7.2823 & -2.6587 & -6.3232 & 0.6701 & -2.3696 \\
\hline Full Sample, Average & 0.2801 & -0.1023 & -0.2432 & 0.0258 & -0.0911 \\
\hline Vintage Period-89/90, Sum & 1.3853 & 0.1041 & -0.4250 & 0.0000 & 1.0643 \\
\hline New REIT Era, Sum & 2.7108 & -0.2238 & -3.7530 & 0.0423 & -1.3083 \\
\hline Initial REIT Maturity Era, Sum & 3.5951 & -0.6699 & -0.9516 & -0.0878 & 2.0615 \\
\hline REIT Maturity Era, Sum & 3.1861 & -2.5390 & -2.1451 & 0.6278 & -2.1257 \\
\hline REIT Maturity Era (w/o GFC-II), Sum & 9.3605 & -2.9969 & -2.1451 & -0.0878 & 4.3063 \\
\hline GFC-I, Sum & -2.7870 & -0.0728 & 0.0000 & 0.0000 & -2.8598 \\
\hline GFC-II, Sum & -6.1744 & 0.4580 & 0.0000 & 0.7156 & -6.4320 \\
\hline Year Pair Count: Positive \& Negative & $16 \& 10$ & $10 \& 16$ & $7 \& 19$ & $22 \& 4$ & $14 \& 12$ \\
\hline
\end{tabular}

Panel C: Cumulative; the less-transparent sub-sample; entire sample period and REIT sub-period results

\begin{tabular}{|l|c|c|c|c|c|}
\hline \multicolumn{1}{|c|}{ REIT period } & Within & Between & Entry & Exit & $\Delta$ ROE \\
\hline Full Sample, Sum & 2.1980 & 0.0812 & -3.3494 & -0.2426 & -0.8277 \\
\hline Full Sample, Average & 0.0845 & 0.0031 & -0.1288 & -0.0093 & -0.0318 \\
\hline Vintage Period-89/90, Sum & 1.2766 & -0.0618 & 0.0000 & 0.0000 & 1.2147 \\
\hline New REIT Era, Sum & 2.2848 & -1.7885 & -2.7061 & -0.2762 & -1.9336 \\
\hline Initial REIT Maturity Era, Sum & -1.8165 & 2.5217 & -0.9605 & 0.1784 & -0.4337 \\
\hline REIT Maturity Era, Sum & -1.3634 & 1.9315 & -0.6433 & 0.0336 & -0.1089 \\
\hline REIT Maturity Era (w/o GFC-II), Sum & 2.8826 & 1.4650 & -0.6302 & 0.0336 & 3.6836 \\
\hline GFC-I, Sum & -0.7104 & 0.0922 & 0.0000 & 0.0000 & -0.6183 \\
\hline GFC-II, Sum & -4.2460 & 0.4666 & -0.0131 & 0.0000 & -3.7925 \\
\hline Year Pair Count: Positive \& Negative & $16 \& 10$ & $14 \& 12$ & $9 \& 17$ & $20 \& 6$ & $14 \& 12$ \\
\hline
\end{tabular}

Note: The change in ROE between any two years equals the sum of the Within, Between, and Entry effects minus the Exit effect. Stay, Enter, and Exit refer to the number of REITs that stay, enter, and exit for each of the two-year pairs. In Panels B, C and D, the Vintage Period-89/90, the New REIT Era, the Initial REIT Maturity Era, the REIT Maturity Era, the REIT Maturity Era without GFC, GFC-I and GFC-II cover the cumulative of the results for each component for the sample years (1) (1990 minus 1989), (2) (1991 minus 1990) through (2001 minus 2000), (3) (2002 minus 2001) through (2007 minus 2006), (4) (2002 minus 2001) through (2015 minus 2014), (5) [(2002 minus 2001) through (2007 minus 2006)] \& [(2010 minus 2009) through (2015 minus. 2014)], (6) (2008 minus 2007), and (7) (2008 minus 2007) \& (2009 minus 2008), respectively. The More-transparent sub-sample includes Equity REITs with investment focus on apartments, industrials, offices, regional malls, and shopping centers. The Less-transparent sub-sample includes all other Equity REITs. 
In Panels B and $\mathrm{C}$, the "change in ROE" is surprisingly less for the Less-transparent sub-sample than the Moretransparent sub-sample. Interestingly, the more muted responses to the GFC's unexpected erosions, especially in the "within" effect during the 2007-2008 period, of the Less-transparent sub-sample appear to account for this difference.

\subsection{Uni-variate tests}

We examine a set of 100 mean and/or median difference tests to examine whether:

- the "within" effect differs from the "between" effect in the (1) Full sample, (2) More-transparent subsample, and (3) Less-transparent sub-sample across the entire sample period or sub-sample periods, as specified above and unique to the REIT industry;

- each of the "within" and "between" effects, as measured for the More-transparent sub-sample, differs from their counterparts, as measured for the Lesstransparent sub-sample, across the entire sample period and the unique sub-sample periods.

These tests, not reported in a table to save space, are to provide an answer for some of our hypotheses as put forth in the Development of Hypotheses section above. We acknowledge in advance that small sample size constraint limits the scope of each of these tests. Overall, coupled with the results in the Uni-variate Results section above, evidence continues to show, albeit not as strongly as we expected, the dominance of the "within" effect. That is, the sample REITs' annual "changes in ROE" originate more from the surviving firms' growth over time.

Parametric tests reveal statistically significant positive differences, mostly at the $5 \%$ level, ${ }^{17}$ in the means of:

- \{“within" minus "between" $\}$ effects in the (1) Full and

(2) More-transparent sub-sample during the REIT Maturity Era after excluding the GFC's influences;

- \{ "between" minus "between" $\}$ effects, for the Lesstransparent sub-sample, between (1) the Initial REIT Maturity Era and the New REIT Era and (2) the REIT Maturity Era and the New REIT Era;

- \{ "between" minus "between" $\}$ effects between the Less-transparent sub-sample and the More-transparent sub-sample during (1) the REIT Maturity Era, (2) the Initial REIT Maturity Era, and (3) the REIT Maturity Era without the GFC's effects.

The Wilcoxon sign-rank or Wilcoxon rank-sum tests on the same comparisons reveal weakly significant median

\footnotetext{
${ }^{17}$ The REIT Maturity Era post-GFC is not a period of focus in this study. Yet, the tests on the mean differences of the "between" effects during this period, (i.e., 2009-2010 through 2014-2015) and the Initial REIT Maturity Era (i.e., 2000-2001 through 2006-2007) for the full sample and the Less-transparent sub-sample are negative and significant. That is, the "between" effect was more pronounced for the Less-transparent sub-sample during the initial years than during the post-GFC years of the REIT Maturity Era.
}

differences in the "within" minus "between" effects in the (1) Full sample and (2) More-transparent sub-sample during the REIT Maturity Era after excluding the GFC's influences.

Keeping in mind the caveat of small sample size, only the positive and significant differences, \{the "within" minus the "between"\} effects, observed for the Full sample and for the More-transparent sub-sample during the REIT Maturity Era after accounting for the GFC's confounding effects, receive support from the parametric and nonparametric tests. All other time-dependent differences between the "within" and the "between" effects appear to be statistically nil.

The More-transparent and the Less-transparent subsamples exhibit some differences. In particular, the Lesstransparent sub-sample's the "between" effect dominates its counterpart during the REIT Maturity Era after excluding the GFC years. This finding is not consistent with our conjecture in the Development of Hypotheses section above. An examination of Panels B and C for this sub-period's sums shows that while the REITs belonging to the Moretransparent segment chose a strategy of surviving REITs' growth over reallocation of resources, those belonging to the Less-transparent sub-sample built a balanced strategy of surviving firms' growth and reallocation of resources. It appears that the maturity reached by the industry has been more beneficial to the Less-transparent segment than the More-transparent segment, raising the possibility that the Less-transparent segment is closer in transparency today than before to the More-transparent segment.

\subsection{OLS results}

Table 5 reports the OLS estimation results on the annual "changes in ROE," the "within" effect component, and the "between" effect component for the Full sample, the More-transparent sub-sample and the Less-transparent sub-sample, respectively. We noted earlier that a few number of REITs had grown quite a bit in the time period leading up to the first REIT listing in the S\&P500 Index in early October 2001, opening the door for the beginning of the REIT Maturity Era. Results from rather small sample of 26 annual observations with only three independent variables offer no support for the conjecture that industry concentration, as measured by HHI, affects the industry's profitability changes, its "within" effect or "between" effect components.

The concern for the degrees of freedom from a sample size of 26 annual observations on the dependent variables forces us to specify rather simple estimation models. That is, only three independent variables, which we discuss under the Development of Hypotheses section above, enter the OLS models:

a) The aggregated REIT industry annual market valuations (in natural log) controls for the association between the observed increases in the REIT industry's market valuations, evident in Figure 1, and the industry's measured profitability metrics; 
Table 5. OLS results on the annual changes in ROE, the "within" effect and the "between" effect

\begin{tabular}{|l|c|c|c|c|c|c|c|c|c|}
\hline & \multicolumn{3}{|c|}{ REIT industry } & \multicolumn{2}{c|}{ More-transparent sectors } & \multicolumn{3}{c|}{ Less-transparent sectors } \\
\cline { 2 - 10 } & $\begin{array}{c}\text { ROE } \\
\text { chng. }\end{array}$ & $\begin{array}{c}\text { Within } \\
\text { effect }\end{array}$ & $\begin{array}{c}\text { Between } \\
\text { effect }\end{array}$ & $\begin{array}{c}\text { ROE } \\
\text { chng. }\end{array}$ & $\begin{array}{c}\text { Within } \\
\text { effect }\end{array}$ & $\begin{array}{c}\text { Between } \\
\text { effect }\end{array}$ & $\begin{array}{c}\text { ROE } \\
\text { chng. }\end{array}$ & $\begin{array}{c}\text { Within } \\
\text { effect }\end{array}$ & $\begin{array}{c}\text { Between } \\
\text { effect }\end{array}$ \\
\hline Intercept & -0.083 & -0.086 & 0.012 & -0.083 & -0.098 & 0.022 & $-0.101^{\star}$ & -0.089 & -0.005 \\
\hline$t$-statistic & $(0.075)$ & $(0.085)$ & $(0.018)$ & $(0.102)$ & $(0.109)$ & $(0.021)$ & $(0.057)$ & $(0.073)$ & $(0.020)$ \\
\hline $\begin{array}{l}{[\text { Ln(Average Market }} \\
\text { Capitalization)] }\end{array}$ & 0.004 & 0.003 & -0.001 & 0.003 & 0.004 & -0.001 & 0.004 & 0.003 & 0.000 \\
\hline$t$-statistic & $(0.003)$ & $(0.004)$ & $(0.001)$ & $(0.004)$ & $(0.004)$ & $(0.001)$ & $(0.003)$ & $(0.003)$ & $(0.001)$ \\
\hline$[$ Ln(Number of IPOs)] & 0.006 & 0.008 & -0.001 & 0.007 & 0.008 & -0.001 & 0.007 & $0.009 *$ & -0.001 \\
\hline$t$-statistic & $(0.005)$ & $(0.005)$ & $(0.001)$ & $(0.007)$ & $(0.007)$ & $(0.001)$ & $(0.005)$ & $(0.005)$ & $(0.001)$ \\
\hline$[$ HHI] & 0.413 & 0.422 & 0.049 & 0.423 & 0.568 & -0.077 & 0.553 & 0.382 & 0.258 \\
\hline$t$-statistic & $(1.058)$ & $(1.193)$ & $(0.242)$ & $(1.374)$ & $(1.487)$ & $(0.288)$ & $(0.842)$ & $(0.979)$ & $(0.249)$ \\
\hline Observations & 26 & 26 & 26 & 26 & 26 & 26 & 26 & 26 & 26 \\
\hline$R$-squared & 0.108 & 0.149 & 0.134 & 0.073 & 0.095 & 0.134 & 0.150 & 0.191 & 0.220 \\
\hline
\end{tabular}

Note: $\operatorname{Ln}$ (Average Market Capitalization), Ln(Number of IPOs), and HHI are the natural log of \{total market capitalization of all relevant sample Equity REITs / the number of Equity REITs $\}$ in a sample year, the natural logarithm of the number of IPOs in the US financial markets in a sample year, and the annual Herfindahl-Hirschman Index (HHI) for the REIT industry, respectively. Data are from NAREIT for the average market capitalization, Jay Ritter's website for the annual number of IPOs in the US, and COMPUSTAT for HHI. Numbers in parentheses are robust standard errors. * indicates statistical significance at the $10 \%$ level.

b) The annual number of IPOs in the U.S. financial markets (in natural log) controls for how access to the financial markets relates to the industry's profitability metrics; and

c) The HHI, which captures the effect of the industry concentration on its profitability.

The only coefficient estimate in Table 5 that attains significance (at the 10\% level) is positive and for the annual number of IPOs under the "within" effect of the Lesstransparent sub-sample. All others coefficient estimates are insignificant in this table.

\section{Conclusions}

Our findings lead to a few novel and interesting conclusions about the REIT industry's profitability performance between 1989 and 2015. To the extent that our Equity REIT sample proxies for the FTSE NAREIT All Equity Index, our conclusions also relate to this index's performance between 1989 and 2015.

First, the sum of improved profitability of individual REITs (i.e., the "within" effect) is considerably much larger than the sum of the temporal profitability changes of the REIT industry. Two factors offset the "within" effect's influence. The sum of the shifts of resources from less to more profitable REITs (i.e., the "between" effect) is unexpectedly negative. Further, the GFC years between the 2007-2009 period generates a massive negative sum in the "within" effect and a slightly positive sum in the "between" effect. Removal of the sums pertaining to the GFC years amplifies more visibly the opposite movements of the "within" and "between" effects during the entire sample period. The same removal also boosts the sum of the temporal changes in $\mathrm{ROE}$ from $-1.42 \%$ to $3.82 \%$ for the REIT industry.
Second, when cleaned from the GFC's confounding effects, the sum of the "within" effect during the REIT Maturity Era (i.e., 2001 through the present time) is about $7.09 \%$. This is 2.5 times larger than its counterpart, $2.8 \%$, during the New REIT Era (i.e., 1991 through 2000). The corresponding figures of the "between" effect and the temporal changes in ROE are $-1.04 \%$ and $-0.88 \%$ and $4.18 \%$ and $-1.52 \%$, respectively.

While the statistical tests on small sample sizes offer only limited evidence of the differences in either the means or the medians for the conclusions in the paragraphs above, the sums demonstrate that the improved profitability of the surviving REITs was the dominant force of the annual profitability changes of the REIT industry.

Other clear, yet surprising, conclusions arise from examining the sums of the Bennet effects under the GFC years. Both the resilience of the shifts of resources from less to more profitable REITs, especially during the 2007-2009 period, and the sudden and prompt contraction in the profitability of the surviving REITs are surprising. Clearly, the "between" effect acted as a partial risk management tool in remedying some of the GFC-driven damages to the REIT industry's profitability, especially to its "within" effect. Comparisons of the results between the More- and Less-transparent subsamples strengthen these conclusions.

Third, we focus mainly on the "within" and "between" effects. Yet, a few comments are in order for the REITs that enter the industry since they appear to exhibit a negative effect on the industry's profitability changes. Given that entering firms transform into surviving REITs, we infer that the entering firms learn promptly lessons from their junior years and rectify their operations to compete well with the others in this industry. These results appear largely consistent with Schumpeter's (1950) views even though the REIT industry operates under governmental distortions. 
Finally, what can we say about the industry's economic efficiency? It is surprising that we are able to locate only one recent study on the economic efficiency of the REIT industry (Highfield et al., 2021). The observed evidence of diseconomies of scale in this industry comes from cost function specifications from the late 1990s or early 2000 s (Ambrose et al., 2000, 2005; Anderson et al., 2002; Miller et al., 2006) and cost, revenue or profit function specifications between 2000 and 2015 (Highfield et al., 2021) and is not inconsistent with a negative sum in the annual changes in ROE during the New REIT Era. A closer look reveals that the surviving REITs exert cumulatively a positive "within" effect and a negative "between" effects. Entering firms are the main source of the negative sum in the changes of ROE during this REIT era. This observation makes some sense since the entry barriers and being potentially less experienced in the industry are likely to bump up these REITs' cost structures.

An examination of the results for the REIT Maturity Era after removing the GFC's effects shows a positive sum in the annual changes in ROE. The "within" effect drives this result by itself. The cumulatively negative "between" and the "entry" effects counter the "within" effect during this period. Our annual and cumulative results for the REIT Maturity Era hint that improvements in the industry's economic efficiency may have occurred. These results, however, appear not to be driven by firm size or concentration in the industry and are overall consistent with the findings in Highfield et al. (2021). These points resonate well with the Bennet decomposition approach and suggest another research avenue in the scale economies literature.

REITs are interesting and increasingly more important to the financial markets. Our paper demonstrates that the REIT industry is no less!

\section{Acknowledgements}

Our thanks go to Erkan Yonder, Steve Cauley, Audrius Banaitis (the editor), the Homer Hoyt Institute participants, as well as Brad Case and NAREIT for data. To save space, we do not report some results that we discuss in the paper. These results are available upon request from the corresponding author.

\section{Disclosure statement}

We have no known conflict to report.

\section{References}

Ambrose, B. W., Ehrlich, S. R., Hughes, W. T., \& Wachter, S. M. (2000). REIT economies of scale: fact or fiction? Real Estate Economics, 20(2), 211-224.

https://doi.org/10.1023/A:1007881422383

Ambrose, B. W., Highfield, M. J., \& Linneman, P. D. (2005). Real estate and economies of scale: the case of REITs. Journal of Real Estate Finance and Economics, 33(2), 323-350. https://doi.org/10.1111/j.1540-6229.2005.00121.x
Anderson, R. I., Fok, R., Springer, T., \& Webb, J. (2002). Technical efficiency and economies of scale: a non-parametric analysis of REIT operating efficiency. European Journal of Operational Research, 139(16), 598-612. https://doi.org/10.1016/S0377-2217(01)00183-7

Bailey, M. N., Hulten, C., \& Campbell, D. (1992). The distribution of productivity. Brookings Papers on Economic Activity: Microeconomics, 1, 187-267. https://doi.org/10.2307/2534764

Balk, B. M. (2003). The residual: on monitoring and benchmarking firms, industries, and economies with respect to productivity. Journal of Productivity Analysis, 20, 5-47.

https://doi.org/10.1023/A:1024817024364

Bartelsman, E., Haltiwanger, J., \& Scarpetta, S. (2004). Microeconomic evidence of creative destruction in industrial and developing countries (Policy Research Working Paper Series No. 3464). World Bank. https://doi.org/10.1596/1813-9450-3464

Bennet, T. L. (1920). The theory of measurement of changes in the cost of living. Journal of the Royal Statistical Society, 83, 455-462. https://doi.org/10.2307/2340960

Ben-Shahar, B., Sulganik, E., \& Tsang, D. (2011). Funds from operations versus net income: examining the dividend relevance of REIT performance measures. Journal of Real Estate Research, 33(3), 415-441.

https://doi.org/10.1080/10835547.2011.12091308

Bhattacharya, N., Black., E. L., Christensen T. E., \& Larson, C. R. (2003). Assessing the relative informativeness and permanence of pro forma earnings and GAAP operating earnings. Journal of Accounting and Economics, 36, 285-319. https://doi.org/10.1016/j.jacceco.2003.06.001

Cakici, N., Erol, I., \& Tirtiroglu, D. (2014). Tracking the evolution of idiosyncratic risk and cross-sectional expected returns for US REITs. Journal of Real Estate Finance and Economics, 48(3), 415-440. https://doi.org/10.1007/s11146-013-9410-7

Chen, H., Downs, D. H., \& Patterson, G. A. (2012). The information content of REIT short interest: investment focus and heterogeneous beliefs. Real Estate Economics, 40(2), 249-283. https://doi.org/10.1111/j.1540-6229.2011.00312.x

Devos, E., Scofield, D., Smith, G., \& Spieler, A. C. (2018). Organization capital and REIT returns [Unpublished manuscript]. Ryerson University, Real Estate Management Department.

Diewert, W. E. (2005). Index number theory using differences rather than ratios. The American Journal of Economics and Sociology, 64, 311-360. https://doi.org/10.1111/j.1536-7150.2005.00365.x

Federal Reserve Bank of Chicago. (2020, September). Commercial bank data. https://www.chicagofed.org/banking/financialinstitution-reports/commercial-bank-data

Feng, Z., Price, S. M., \& Sirmans, C. F. (2011). An overview of equity real estate investment trusts (REITs): 1993-2009. Journal of Real Estate Literature, 19, 307-343. https://doi.org/10.1080/10835547.2011.12090304

Fisher, I. (1922). The making of index numbers. Houghton Mifflin.

Griliches, Z., \& Regev, H. (1995). Firm productivity in Israeli industry, 1979-1988. Journal of Econometrics, 65, 175-203. https://doi.org/10.1016/0304-4076(94)01601-U

Haltiwanger, J. C. (1997). Measuring and analyzing aggregate fluctuations: the importance of building from microeconomic evidence. Review, 79(3), 55-77. https://doi.org/10.20955/r.79.55-78

Highfield, M. J., Shen, L., \& Springer, T. M. (2021). Economies of scale and the operating efficiency of REITs: a revisit. Journal of Real Estate Finance and Economics, 62(1), 108-138. https://doi.org/10.1007/s11146-019-09741-9 
Jeon, Y., \& Miller, S. M. (2005). An 'ideal' decomposition of industry dynamics: an application to the nationwide and state level U.S. banking industry (Working Paper No. 2005-25). Department of Economics, University of Connecticut. http://ideas.repec.org/p/uct/uconnp/2005-25.html

Laspeyres, E. (1871). Die berechnung einer mittleren warenbpreissteigerung. Jahrbücher für Nationalökonomie und Statistik, 16, 296-314. https://doi.org/10.1515/jbnst-1871-0124

Lougee, B. A., \& Marquardt, C. A. (2004). Earnings informativeness and strategic disclosure: an empirical examination of 'pro forma' earnings. The Accounting Review, 79(3), 769-795. https://doi.org/10.2308/accr.2004.79.3.769

McGuckin, R. H. (1995). Establishment microdata for economic research and policy analysis: looking beyond the aggregates. Journal of Business and Economic Statistics, 13, 121-126. https://doi.org/10.1080/07350015.1995.10524585

Miller, S. M., Clauretie, T. M., \& Springer, T. M. (2006). Economies of scale and cost efficiencies: a panel-data stochasticfrontier analysis of real estate investment trusts. The Manchester School, 74(4), 483-489. https://doi.org/10.1111/j.1467-9957.2006.00505.x

National Association of Real Estate Investment Trusts. (2020a, September). U.S. REIT industry equity market cap. https:// www.reit.com/data-research/reit-market-data/us-reit-industry-equity-market-cap
National Association of Real Estate Investment Trusts. (2020b, September). Glossary of REIT terms.

https://www.reit.com/what-reit/glossary-reit-terms

National Association of Real Estate Investment Trusts. (2020c, September). REIT's: real estate working for you.

https://www.reit.com/

Paasche, H. (1974). Über die preisentwicklung der letzten jahre nach den Hamburger börsennotirungen. Jahrbücher für $\mathrm{Na}$ tionalökonomie und Statistik, 24, 168-178.

Pigou, A. C. (1920). The economics of welfare. MacMillan.

Prescott, E. C., \& Visscher, M. (1980). Organization capital. The Journal of Political Economy, 88(3), 446-461. https://doi.org/10.1086/260879

Ritter, J. R. (2020, September). IPO data. https://site.warrington. ufl.edu/ritter/ipo-data/

Scarpetta, S., Hemmings, P., Tressel, T., \& Woo, J. (2002). The role of policy and institutions for productivity and firm dynamics: evidence from micro and industry data (Working Paper No. 329). OECD Publishing. https://doi.org/10.2139/ssrn.308680

Schumpeter, J. A. (1950). The process of creative destruction. Harper \& Row.

Stiroh, K. J. (2000). Compositional dynamics and the performance of the U.S. banking industry (Staff Reports No. 98). Federal Reserve Bank of New York. https://doi.org/10.2139/ssrn.221949 